\section{Germination and seed ecology of Buchenavia tomentosa Eichler (Combretaceae)}

\author{
Amanda Ribeiro Correa ${ }^{*}{ }^{*}$, Ana Mayra Pereira da Silva ${ }^{1}$ iD , Vitor Sthevan \\ Mendes da Silva ${ }^{1}$ (D) , Elisangela Clarete Camili ${ }^{1}$ (D) , Antonio Renan Berchol \\ da Silva² ${ }^{2}$, Maria de Fátima Barbosa Coelho ${ }^{1}$ iD
}

ABSTRACT: Buchenavia tomentosa produces fruits with ecological function for Cerrado's fauna. The aims of this paper were to quantify seed germination and behavior on thermal conditions and explain about water absorption of dispersal structure in $B$. tomentosa seeds. Ripe fruits were pulped, the endocarp removed, and seeds used in the germination tests at temperatures of 10 to $45^{\circ} \mathrm{C}$. Seeds were placed in rolls of filter paper and then placed in germination chambers, at twelve hours of photoperiod. Germination models at sub and supra optimal temperatures were made from the germination rate $\left(T_{g}\right)$, from the time to germination of $50 \%$ of the seeds $\left(t_{50}\right)$. Germination speed index (GSI), measurements of shoot and root lengths and dry mass at each temperature were obtained. The water imbibition curve of seed with or without endocarp adhered and scarified or not was made and other samples were tested for emergence in sand. Cardinal temperatures were: base temperature $\left(T_{b}\right)$ of $9.23{ }^{\circ} \mathrm{C}$; maximum temperature $\left(T_{\max }\right)$ of $44.6^{\circ} \mathrm{C}$; optimum temperature $\left(\mathrm{T}_{\mathrm{o}}\right)$ of $29.24^{\circ} \mathrm{C}$ and thermal time of $89.71^{\circ} \mathrm{C}$.days. Seedlings showed higher GSI, root and aerial part length and higher root dry mass at the optimal temperature. The endocarp retards, but does not prevent water absorption and emergence.

Index terms: mirindiba-do-Cerrado, boca-boa, thermal time model, germination model, endocarp.

\section{Germinação e ecologia de sementes de Buchenavia tomentosa Eichler (Combretaceae)}

RESUMO: Buchenavia tomentosa produz frutos com função ecológica para a fauna do Cerrado. Objetivou-se, neste trabalho, quantificar a germinação e o comportamento das sementes em condições térmicas e esclarecer a absorção de água pela estrutura de dispersão de $B$. tomentosa. Frutos maduros foram despolpados, o endocarpo removido, e as sementes utilizadas nos testes de germinação, às temperaturas de $10 \mathrm{a} 45^{\circ} \mathrm{C}$. As sementes foram colocadas em rolos de papel e em seguida em câmaras de germinação sob doze horas de fotoperíodo. Modelos de germinação em temperaturas sub e supra ótimas foram obtidos por meio da taxa de germinação $\left(T_{g}\right)$ ), a partir do tempo para germinação de $50 \%$ das sementes $\left(t_{50}\right)$. Índice de velocidade de germinação (GSI), medidas dos comprimentos e massas secas da parte aérea e raiz das plântulas em cada temperatura foram obtidos. A curva de embebição de água das sementes com ou sem endocarpo aderido foi avaliada, e outras amostras testadas quanto à emergência em areia. As temperaturas cardinais foram: temperatura base $\left(T_{b}\right)$ de $9,23^{\circ} \mathrm{C}$; máxima $\left(T_{\max }\right)$ de $44,6{ }^{\circ} \mathrm{C}$; ótima $\left(T_{0}\right)$ de 29,24 ${ }^{\circ} \mathrm{C}$ e soma térmica de $89,71^{\circ} \mathrm{C}$.days. As plântulas apresentaram maior comprimento das raízes e parte aérea e maior massa seca das raízes na temperatura ideal. 0 endocarpo retarda, mas não impede a absorção de água e emergência das sementes.

Termos para indexação: mirindiba-do-Cerrado, boca-boa, modelo térmico, modelos de germinação, endocarpo.
Journal of Seed Science, v.42, e202042007, 2020

http://dx.doi.org/10.1590/23171545v42223782 


\section{INTRODUCTION}

Germination occurs at a minimum cardinal temperature range $\left(T_{b}\right)$, below which the germination process does not occur; a maximum temperature $\left(T_{\max }\right)$, above which the germination is not complete; and, an optimum temperature $\left(T_{0}\right)$, in which the germination speed is faster. Cardinal temperatures serve as basis of predictive models, due to the frequently linear relationship found between germination rate $\left(T_{g}\right)$ and temperature, in sub and supra-optimal models (Bradford, 2002). The relationship of linearity makes possible to estimate thermal models for the time required, in ${ }^{\circ} \mathrm{C}$ days ( ${ }^{\circ} \mathrm{C}$.days) until the conclusion of germination (Bradford, 2002) as in Silybum marianum seeds (Parmoon et al., 2015), crop species (Tribouillois et al., 2016) and spontaneous species (Hardegree, 2006).

Some thermal studies based on germinations models were carried with seeds of tropical forest (Mattana et al., 2018; Lamarca et al., 2011; Cardoso and Pereira, 2009). These studies can be useful to understand ecological aspects related to seed germination, such as the basis and optimal temperature for seed germination and vigor. These factors can support models for the seedlings' establishment in some areas, as well as resilience of plant communities on habitat.

Another factor related to germination are adaptive seed dispersal structures, important for the survival of some species in the habitat, such the protection of embryo against the fire passage, as in macaw palm (Bicalho et al., 2016). The endocarp still helps to maintain the moisture content for complete seed germination and establishment (Mattana et al., 2018).

However, dispersal structures interfere on germinative aspects, such as water absorption, dormancy induction and time to germination in optimum conditions, as in Byrsonima basiloba (Silveira et al., 2012) and Empetrum hermaphroditum (Baskin et al., 2002). These diaspores may present palisade layers responsible for the physical barrier of water entry and induce physical seed dormancy (Baskin and Baskin, 2014), or increase the time to germination.

Buchenavia tomentosa Eichler (Combretaceae) is an important species which occurs in Cerradão, semideciduous forest, ciliary forest, gallery forest, dry and Cerrado forest (Mendonça et al., 2008). It's known as mirindiba-do-Cerrado, mirindiba and boca-boa, with fruits elliptic or with spherical drupes ranging from 2 to $5 \mathrm{~cm}$ in diameter, with yellow pericarp and stony endocarp (Campos Filho and Sartorelli, 2015). The species presents stone endocarp adhered in their seeds.

B. tomentosa presents intense fruit production, important for the maintenance of Cerrado's flora and fauna, and the fruits are efficiently propagated by several animals, such as ants, deer and mainly by tapir, which consume the pulp. On the tapir's case, the seeds pass through the digestive tract, favors the removal of pulp adhered to the fruits and does not affect the germination potential (Farias et al., 2015). The dispersers can still contribute to the endocarp's remover and faster species populations' formation at Cerrado.

For B. tomentosa, thermal time models to seed germination and the study based on ecology of dispersal structure contribute to the understand the species' evolution at Cerrado areas and is able to provides data to help predict seed germination in future scenarios of temperature increase. In addition, $B$. tomentosa seed ecology studies may predict the competition of seed germination and maintenance against other natives and exotic plants and animal predation.

The aims of this study were to quantify germination and seed behavior on thermal conditions and water absorption of dispersal structure in $B$. tomentosa seeds.

\section{MATERIAL AND METHODS}

Ripe and yellow fruits of $B$. tomentosa were harvested from plants at Cerrado, their native habitat, after natural dispersion of matrices located in Cuiabá, $\mathrm{MT}\left(15^{\circ} 61^{\prime} \mathrm{S}, 56^{\circ} 65^{\prime} \mathrm{W}\right)$. The annual average temperature is $28^{\circ} \mathrm{C}$, and maximum and minimum average air temperature are 34 and $22^{\circ} \mathrm{C}$, respectively (Figure 1). Every year, maximum air temperatures of the region reach around $40{ }^{\circ} \mathrm{C}$ on many days during spring and summer (INMET, 2018), periods that coincide with wet seasons. Cerrado is characterized by a dry season from April to September (from mid-autumn to early spring) and a wet season from October to March (from mid-spring to early autumn) (Reys et al., 2013).

The fruits were pulped, washed, and the seeds with endocarp adhered were placed to dry on filter paper for 24 


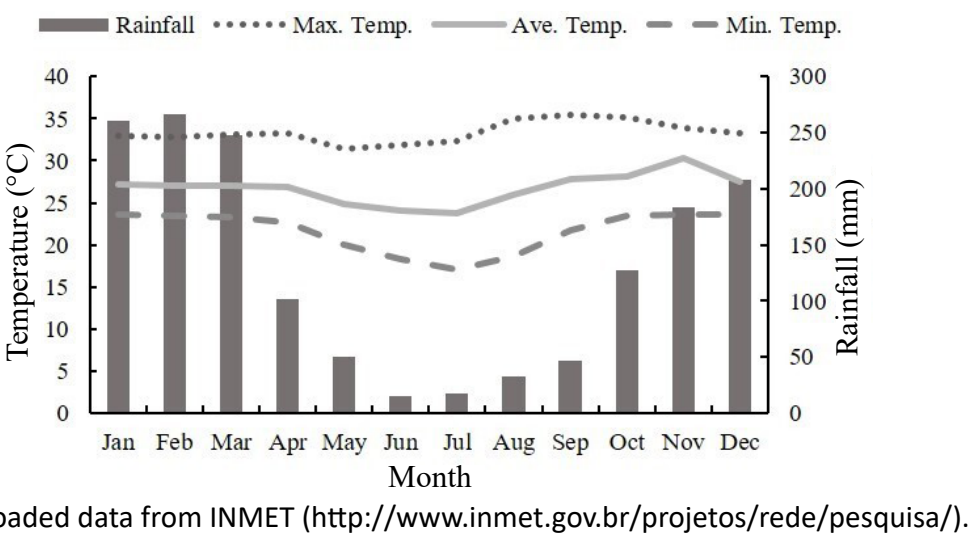

Figure 1. Maximum, average and minimum air temperature (max. temp., ave. temp. and min. temp., respectively) and rainfall of region in the last twenty years.

hours at $27.65 \pm 3{ }^{\circ} \mathrm{C}$ and $54.39 \pm 3 \%$ of relative humidity $(\mathrm{RH})$. Then, the seeds were submitted to drying, to determine water content, at $105 \pm 3{ }^{\circ} \mathrm{C}$ for 24 hours (Brasil, 2009). The water content was $11 \%$. They were then stored in a refrigerated chamber at $18 \pm 2{ }^{\circ} \mathrm{C}$, and $\mathrm{RH}$ of $63 \pm 4 \%$, for two weeks until the tests.

The seeds were submitted to germination test from 10 to $45^{\circ} \mathrm{C}$, at intervals of $5{ }^{\circ} \mathrm{C}$, with photoperiod of twelve hours, in germination chambers. Due to damaging fungal interference and for higher accuracy determination of cardinal temperatures, the endocarp was mechanically removed from seeds using a hydraulic press at $0.8 \mathrm{t}$, and the seeds used in the thermal parameters.

The seeds were placed to germinate on a filter paper substrate, moistened with distilled water in the proportion of 2.5 the mass of the dry paper, with four replications of 25 seeds per temperature. The water replacement was performed daily to maintain always the initial proportion of water in both temperatures. The seeds were considered as germinated after emission of $2 \mathrm{~mm}$ of primary root, and germinations were counted daily for one month. The results were expressed as percentage of germination (Brasil, 2009).

For seedling behavior evaluation, germination speed index (GSI) was determined based on Maguire (1962). Also, ten seedlings were randomly chosen of each replication of the germination test, in each temperature. Root and shoot length were evaluated at fifteen days of the beginning of the germination test. The same ten seedlings were weighed on an analytical balance (accuracy of $\pm 0.01 \mathrm{~g}$ ) and then placed in aluminum capsules for drying at $80 \pm 1{ }^{\circ} \mathrm{C}$ for 24 hours, to determine the dried root masses and aerial part (Nakagawa, 1999).

In order to simulate differences in hydration by seeds, curves of water absorption were made for seeds with intact endocarps, seeds with scarified endocarps (with the aid of an emery) and seeds without endocarp (removed mechanically, as in the thermal models experiment). The seeds' water content in all treatment before water absorption was determined by the drying method at $105 \pm 3{ }^{\circ} \mathrm{C}$, for 24 hours, with three replicates of fifteen seeds; and the results expressed as in percentage (\%) of wet mass basis (Brasil, 2009).

For the water absorption curve, five replicates of ten seeds in each treatment were placed to soak on germination paper in an incubator at $30{ }^{\circ} \mathrm{C}$, temperature close to the optimum determined by thermal models. Periodic, weighing was done every hour until the primary root emission with $2 \mathrm{~mm}$, in $50 \%$ of the seeds for replication. The water uptake by the seeds monitored at each weighing was transformed into water content by the Hampton and Tekrony (1995) formula:

$$
B=100-\left[\frac{W_{1}(100-A)}{W_{2}}\right]
$$

Where: $\mathrm{B}$ : water content at the time of evaluation (\%); $\mathrm{W}_{1}$ : initial mass (g); $\mathrm{A}$ : initial water content on wet basis (\%); $\mathrm{W}_{2}$ : mass at the time of evaluation (g).

Differences in seed emergence were tested through the seeds' burial with intact endocarp adhered, scarified endocarp and without endocarp. Five replications of ten seeds per treatment were buried in sand boxes moistened to 
$60 \%$ of the sand's water retention capacity, at $3 \mathrm{~cm}$ depth, and the emergence counted daily. The seeds were placed on the stand, in laboratory condition, at $25 \pm 3{ }^{\circ} \mathrm{C}$ and $50 \pm 6 \%$ of temperature and relative air humidity, respectively, and maintained for twelve hours of photoperiod.

\section{Statistical analyzes}

In the germination experiment, cardinal temperatures were evaluated by determining the germination rate $\left(R_{50}\right)$, defined as the inverse of the time required to reach $50 \%$ germination $\left(t_{50}\right)$ at each temperature tested, considering the phase of germinations' linear response by the time. To estimate the $R_{50}$ parameters, $t_{50}$ was determined in each replicate, by equations of germinations' regression according to the time, and a final mean was established with the standard deviations. $R_{50}$ data were regressed with temperatures, using linear models to estimate the base $\left(T_{b}\right)$ and maximum $\left(T_{\max }\right)$ temperature, in which $R_{50}$ is equal to zero; and the optimum temperature $\left(T_{0}\right)$, when $R_{50}$ is faster, using sub and supra optimal models.

Optimum temperature $\left(T_{0}\right)$ was calculated considering the maximum germination rate to reach $t_{50^{\prime}}$ using the intercept of the sub and supra optimal models, according to Mattana et al. (2018). A thermal time model ( ${ }^{\circ} \mathrm{C}$.days) was adjusted using the following equation at sub (Eq.1) and supra-optimal (Eq.2) temperatures (Bradford, 2002):

$$
\begin{aligned}
T_{\text {sub }} & =\left(T-T_{b}\right) t_{50} \quad \text { (Eq. 1) } \\
T_{\text {supra }} & =\left(T_{\max }-T\right) t_{50} \quad \text { (Eq. 2) }
\end{aligned}
$$

$T_{\text {sub }}$ is the thermal time to germination at sub-optimal temperatures; $T$ is the germination temperature; $T_{b}$ is the base temperature; $\mathrm{T}_{\text {supra }}$ is the time to germination at supra-optimal temperatures; $\mathrm{T}_{\max }$ is the germination maximum temperature.

The time to emergence of $50 \%\left(\mathrm{te}_{50}\right)$ of the seedlings was calculated similarly to the thermal time experiment, by equations of regression of emergences as a function of time (days). Parameters of thermal time to germination, final percentage of germination and seedling emergence were estimated by Excel software; and $t_{50}$ data, final germination percentage, GSI, seedling length and mass were submitted to normality test and compared by Anova $(p<0,05)$ and Tukey test $(p<0,05)$ on the SISVAR software.

\section{RESULTS AND DISCUSSION}

Dynamics of cumulative germination by the time of $B$. tomentosa seeds without endocarp adhered varied at different temperatures. The time to reach $t_{50}$ was faster at $30^{\circ} \mathrm{C}$, with $4.5 \pm 0.45$ days, despite at $25{ }^{\circ} \mathrm{C}$ the $t_{50}$ did not differ statistically (Figure 2). The $\mathrm{t}_{50}$ was slower at 15 and $40^{\circ} \mathrm{C}$; at 20 or $35^{\circ} \mathrm{C}$ the seed behavior was also similar (Figure 2). These results show that changes in temperatures below $25^{\circ} \mathrm{C}$ and above $30{ }^{\circ} \mathrm{C}$ become effective in reducing the germination time of $50 \%$ of $B$. tomentosa seeds, and this reduction is quantitatively similar at both sub and supra optimal temperatures.

By using equations of the time to reach $50 \%$ of germination $\left(t_{50}\right)$ (Table 1$)$, it was possible to estimate germination rate $\left(R_{50}\right)$ and model's parameters to the cardinal temperatures in suboptimal and supra-optimal temperatures (Figure 3). The basis temperatures estimated by germination models (Table 2 ) for $B$. tomentosa is very close to the observed in the experiment, showing the efficacy of the models to predict thermal sum for germination. These values coincide with the ones obtained for other tropical species, especially for Anogeissus leiocarpa $\left(T_{b}\right.$ of $9.65^{\circ} \mathrm{C}$, $\mathrm{T}_{\max }$ of $40.5^{\circ} \mathrm{C}$ ), a Combretaceae family's species occurring at African Savanna (Mattana et al., 2018). The species Melanoxylon brauna $\left(\mathrm{T}_{\mathrm{b}}\right.$ of 12.1 to $12.6^{\circ} \mathrm{C}, \mathrm{T}_{\text {max }}$ of 42.4 to $43.0^{\circ} \mathrm{C}$ ) (Flores et al., 2014), Lippia javanica $\left(\mathrm{T}_{\mathrm{b}}\right.$ of $7^{\circ} \mathrm{C}$ ) (Mattana et al., 2017) and Ocotea pulchella ( $\mathrm{T}_{\mathrm{b}}$ of $11^{\circ} \mathrm{C}$ and $\mathrm{T}_{\text {max }}$ of 33 to $42{ }^{\circ} \mathrm{C}$ ) (Pires et al., 2009) also had cardinal temperatures similar as the one determined in this work for $B$. tomentosa.

In relation to $\mathrm{T}_{0}$, Brancalion et al. (2010) found that temperatures close to $25^{\circ} \mathrm{C}$ would be considered optimal for Cerrado's species, based on a database of 95 native species, which was also found for Anogeissus leiocarpa ( $T_{\text {。 }}$ of $24.9^{\circ} \mathrm{C}$ ) (Mattana et al., 2018). However, $\mathrm{T}_{\mathrm{o}}$ of $30-35.8^{\circ} \mathrm{C}$ for other native species, such as Melanoxylon brauna 
(Flores et al., 2014); $\mathrm{T}_{0}$ of 30 to $35^{\circ} \mathrm{C}$ for Tabebuia aurea (Pacheco et al., 2008), and $\mathrm{T}_{\mathrm{o}}$ of 25 to $30^{\circ} \mathrm{C}$ for Eugenia sp. (Lamarca et al., 2011 ) were found close to $\mathrm{T}_{\mathrm{o}}\left(29.24^{\circ} \mathrm{C}\right.$ ) for $B$. tomentosa.

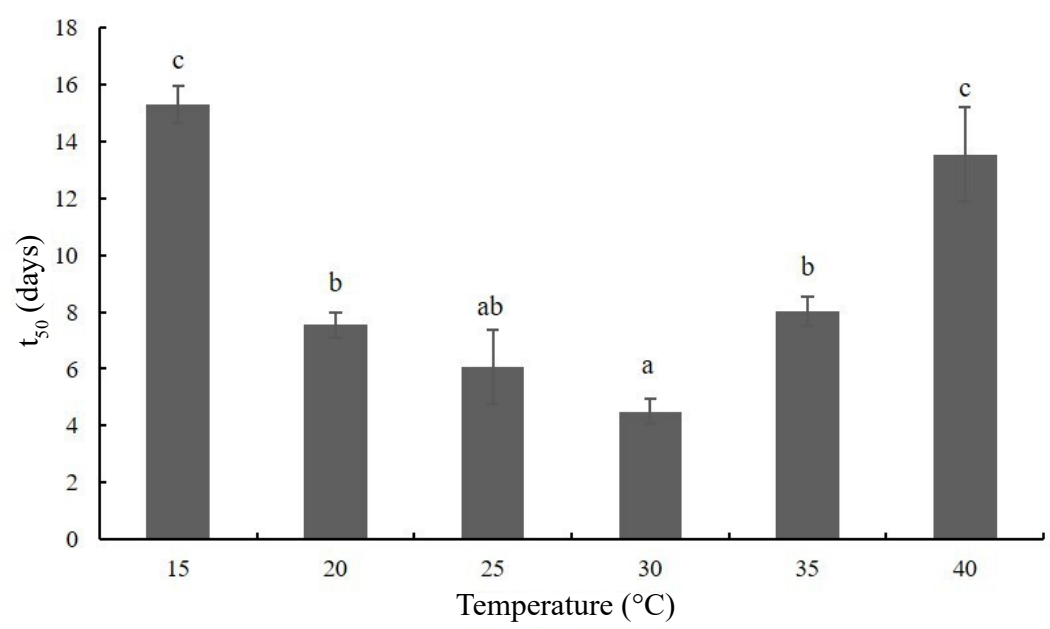

Averages followed by the same letters do not differ by Tukey test $(p<0.05)$. Error bars represent standard errors.

Figure 2. Germination of Buchenavia tomentosa Eichler seeds without endocarp adhered, based on $t_{50}$ values at different incubation temperatures.

Table 1. Equations estimated for seed germination of Buchenavia tomentosa Eichler at constant temperatures, according to the time (days).

\begin{tabular}{ccc}
\hline Temperature $\left({ }^{\circ} \mathrm{C}\right)$ & Equation & $\mathrm{R}^{2}$ \\
\hline 15 & $\mathrm{y}=-1.2262 \mathrm{x}^{2}+38.917 x-262.07$ & 0.93 \\
20 & $\mathrm{y}=-0.9508 \mathrm{x}^{2}+26.084 \mathrm{x}-88.879$ & 0.99 \\
25 & $\mathrm{y}=-1.75 \mathrm{x}^{2}+34.8 \mathrm{x}-89.383$ & 0.99 \\
30 & $\mathrm{y}=-1.4745 \mathrm{x}^{2}+30.765 \mathrm{x}-63.2$ & 0.91 \\
35 & $\mathrm{y}=-0.6926 \mathrm{x}^{2}+21.682 x-75.623$ & 0.99 \\
40 & $\mathrm{y}=-0.0699 \mathrm{x}^{2}+6.2118 \mathrm{x}-27.146$ & 0.94 \\
\hline
\end{tabular}

$R^{2}$ : Coefficient of determination of the regression.

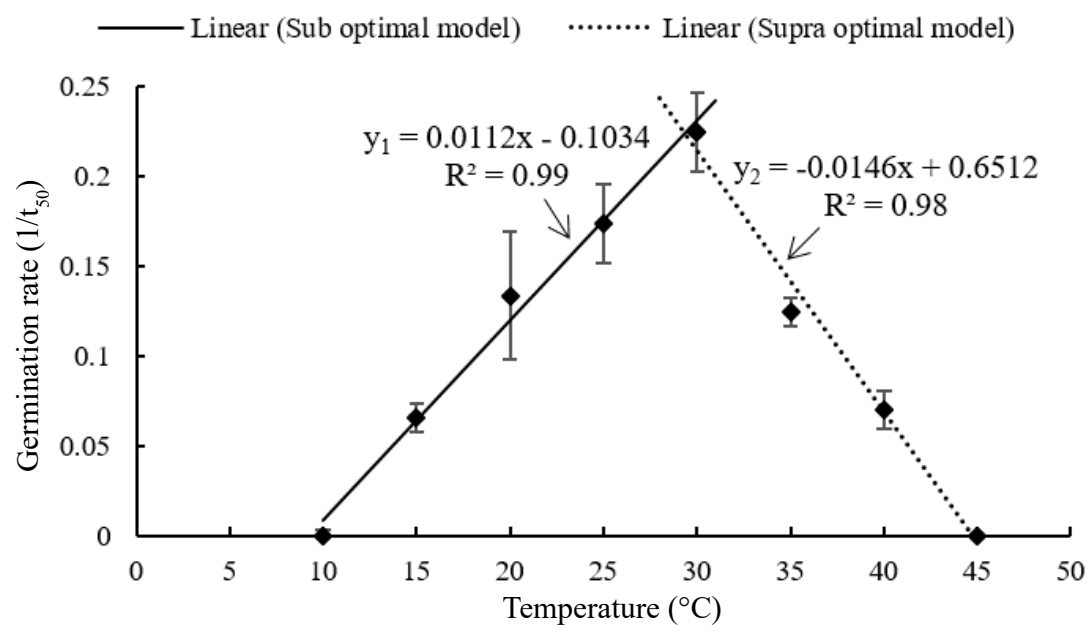

Error bars represent standard errors.

Figure 3. Germination rate of $B$. tomentosa Eichler seeds according to temperature in sub and supra optimal conditions. 
Table 2. Parameters of the sub and supra optimal models for seed germination of Buchenavia tomentosa Eichler.

\begin{tabular}{ccccccc}
\hline Model & Equation & $\mathrm{R}^{2}$ & $\mathrm{~T}_{\mathrm{b}}\left({ }^{\circ} \mathrm{C}\right)$ & $\mathrm{T}_{0}\left({ }^{\circ} \mathrm{C}\right)$ & $\mathrm{T}_{\max }\left({ }^{\circ} \mathrm{C}\right)$ & $\mathrm{TS}\left({ }^{\circ} \mathrm{C}\right.$. days $)$ \\
\hline Sub optimal & $\mathrm{y}_{1}=0.0112 \mathrm{x}-0.1034$ & 0.99 & 9.23 & - & - & 89.71 \\
Supra optimal & $\mathrm{y}_{2}=-0.0146 \mathrm{x}+0.6512$ & 0.98 & - & - & 44.6 & \\
$\mathrm{y}_{1}=\mathrm{y}_{2}$ & - & - & - & 29.24 & - & \\
\hline
\end{tabular}

$R^{2}$ is the coefficient of determination of regression; $T_{b^{\prime}} T_{0}$ and $T_{\max }$ is the base, optimum e maximum germination temperature, respectively. TS: the thermal sum to germination on temperatures.

The germination in a wide temperature range presented by $B$. tomentosa seeds, from 15 to $40^{\circ} \mathrm{C}$, and thermal requirement for maximum speed germination estimated on $29^{\circ} \mathrm{C}$, are high temperature prerequisites compared to species from non-tropical areas (Cochrane et al., 2014; Trudgill et al., 2000). It's usually explained for adaptation and thermal characteristics acquired at native regions (Trudgill et al., 2000).

B. tomentosa is native from Cerrado and Amazon Rainforest. In the first biome, the trees begin to fruit in March, and the dispersal starts in June (Farias et al., 2015); whereas in the second one, the fructification begins in September, with dispersion in May (Camargo et al., 2008). At Cerrado, due to the occurrence of a well-defined dry season and short water during a long part of year (Figure 1), the seeds are able to germinate only at the time of water availability, which coincides with the period of high average temperatures (Brancalion et al., 2010).

Optimum germination temperatures can be determined for seed adaptation to the environment. A recent study showed significant relationship of $\mathrm{T}_{\mathrm{o}}$ and annual average temperature of the occurrence region species (Cochrane et al., 2014). The average temperature of the studied region in the last twenty years was $28^{\circ} \mathrm{C}$ (Figure 1), close to $\mathrm{T}_{0}$ for $B$. tomentosa $\left(29^{\circ} \mathrm{C}\right)$. In this way, the environment may have determined the thermal requirement of high temperatures for seed germination. However, other specific studies are necessary to infer about the influence of the other climatic condition on the thermal requirement for $B$. tomentosa seeds.

Thermal time model (TT) to germination of $50 \%$ of the seeds was average $89.71{ }^{\circ} \mathrm{C}$.days (Table 2). Compared to TT of $196^{\circ} \mathrm{C}$.days for Anogeissus leiocarpa (Mattana et al., 2018), it is a lower thermal requirement, however, the endocarp removal and the faster water absorption in $B$. tomentosa are considered, with consequently less time to complete the germination process. However, in the tropical Verbenaceae species of Lippia genus, which do not present barriers to water absorption, values close to those required by B. tomentosa, from 69 to $84^{\circ} \mathrm{C}$.days to reach $50 \%$ of germination,

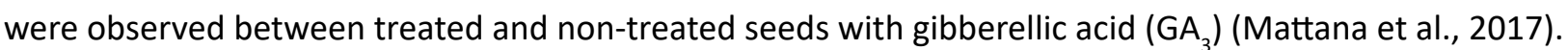

The temperature is still influenced by the final germination percentage; the regression model estimated $80 \%$ of germination at $19.7{ }^{\circ} \mathrm{C}$ and maximum percentage at $28.9^{\circ} \mathrm{C}$ (Figure $4 \mathrm{~A}$ ). Next to the $\mathrm{T}_{\mathrm{b}}$ and $\mathrm{T}_{\text {max }}$, at 15 and $40^{\circ} \mathrm{C}$, the final germination was smaller and differed significantly to the others temperatures (Figure $4 \mathrm{~B}$ ). There was no germination at 10 and $45^{\circ} \mathrm{C}$.

Likewise, highest GSI estimated by model occurred at $28.8^{\circ} \mathrm{C}$ (Figure $4 \mathrm{C}$ ), with significant statistical reduction above or below $30^{\circ} \mathrm{C}$ (Figure 4D), similar to the value obtained in the optimum thermal condition for germination $\left(29.24{ }^{\circ} \mathrm{C}\right)$. Although $\mathrm{t}_{50}$ at $30^{\circ} \mathrm{C}$ did not differed from $25^{\circ} \mathrm{C}$, when considering germination speed of $100 \%$ of the seed population, the differences between the same temperatures become significant.

Around to the optimum temperature $\left(30^{\circ} \mathrm{C}\right)$, seedlings presented a greater length and root dry mass; whereas at aerial part only the length was significantly higher at the optimal temperature (Figures 5A and 5B). At the optimal condition, the root growth rate was $0.74 \mathrm{~cm}_{\text {day }}{ }^{-1}$, faster than other temperatures in the same time period. The higher speed of radicle elongation favors the establishment of seedlings in the environment. When conditions of water availability are not limiting, the seeds can germinate and establish faster in optimal temperatures.

Despite the reduction of final germination percentage only at 15 and $40{ }^{\circ} \mathrm{C}$, the lowest germination speed, the length and root mass of $B$. tomentosa seeds above or below $30{ }^{\circ} \mathrm{C}$ may be significant for seedling survival. Slowgerminating seeds, in non-optimal conditions, unlike faster-germinating seeds, can be predated prior to emergence and subject to competition with other plants for moisture and nutrients (Norden et al., 2009). 

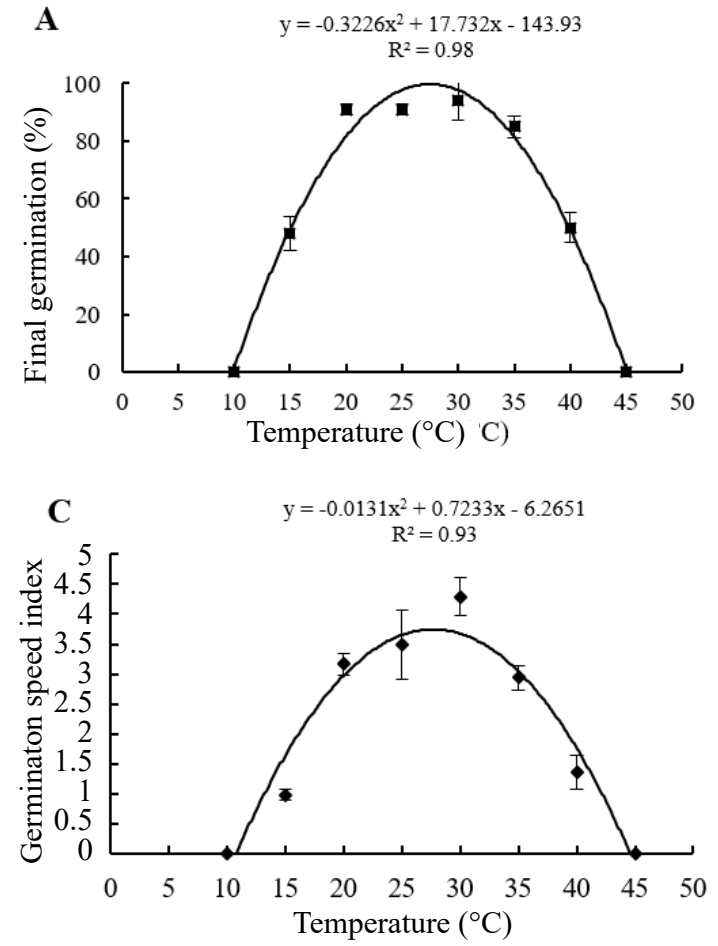

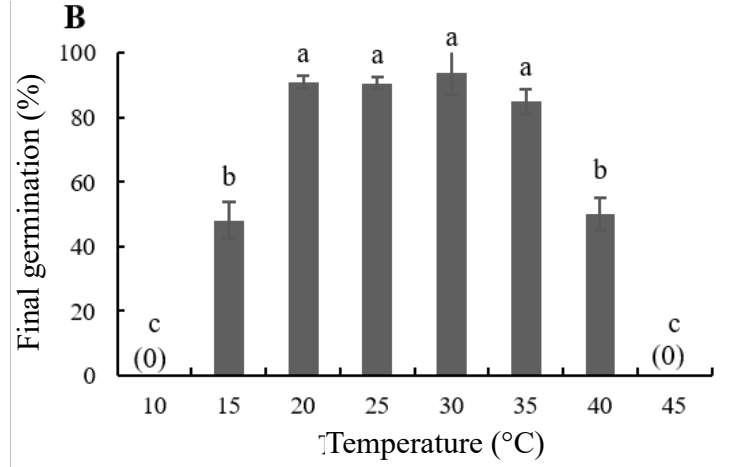

D

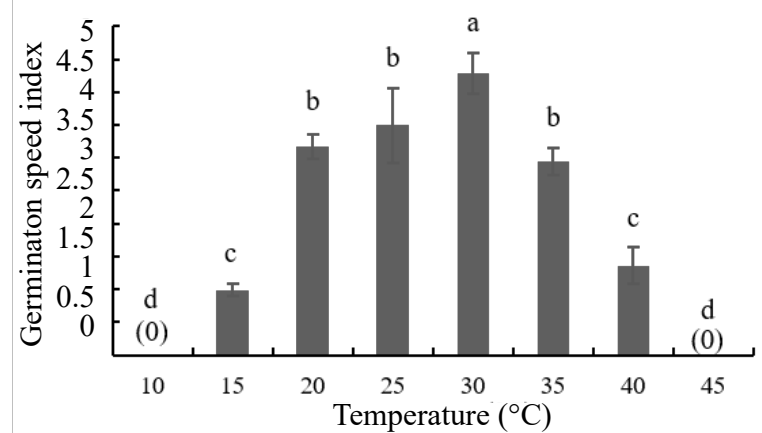

Averages followed by the same letters do not differ by Tukey test $(p<0.05)$. Error bars represent standard errors.

Figure 4. Final germination percentage ( $A$ and $B$ ) and germination speed index ( $C$ and $D)$ of Buchenavia tomentosa Eichler seeds without endocarp adhered at different incubation temperatures.
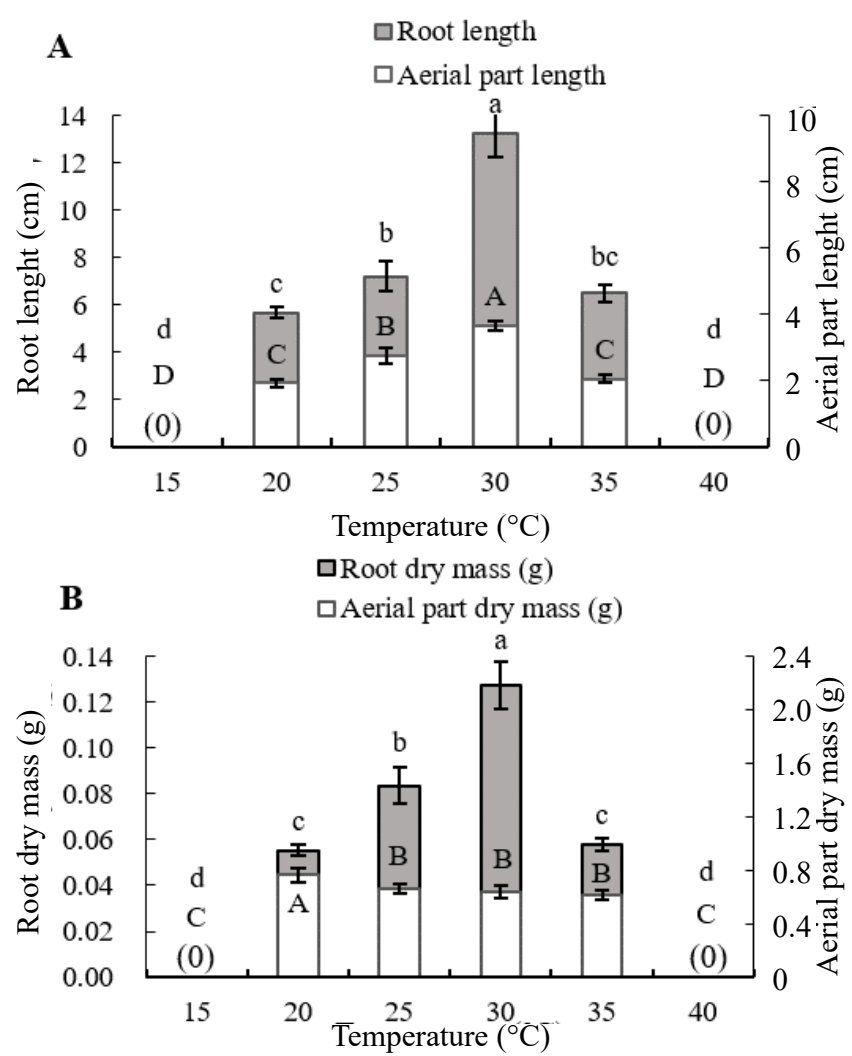

Averages followed by the same letters do not differ by Tukey test $(p<0.05)$. Error bars represent standard errors.

Figure 5. Length (A) and dry mass (B) of the roots and aerial part of Buchenavia tomentosa Eichler seedlings at different incubation temperatures. 
An important fact is that the seed behavior in supra-optimal temperatures around $40{ }^{\circ} \mathrm{C}$, where the seedlings survival is substantially impaired, is relevant in years of elevated temperatures in wet season, condition often found at Cerrado. As well, in future scenarios of temperature increase, the elevations of average daily temperatures and prolonged days with high temperatures delays the $B$. tomentosa seedlings' development, hinders the establishment and competition. Above $40^{\circ} \mathrm{C}$ it is not completed.

Regarding the absorption of water by the seeds without endocarp adhered and with endocarp scarified or not, there was difference in the absorption pattern and in the time to complete the germination. The three phases of water absorption were observed only for seeds without endocarp (Figures 6A and 6B), as reported by Bewley (1997), where the imbibition of most seeds follows a three-phase pattern.

Seeds without endocarp took 36 hours to complete the phase 1 of water absorption (Figure 6A), and they obtained an increase in the wet mass of $23.1 \%$ in relation to the initial water content. In the case of seeds with scarified or nonscarified endocarp adhered, they required 48 hours to complete the same phase (Figure 6B). At this initial period, there is intense absorption of water by the seeds (Bewley and Black, 1994). The acceleration in the imbibition process of seeds without endocarp still occurs in Anogeissus leiocarpa (Mattana et al., 2018) and Byrsonima basiloba (Silveira et al., 2012), due to the remove of the seeds' external mechanic barrier, facilitating the inflow of water during the hydration process.

Despite the absence of the endocarp to benefit the speed of the water imbibition process, there is no physical dormancy in the $B$. tomentosa seeds, since there is no total impediment of water inflow during hydration (Baskin and Baskin, 2004). According to Mattana et al. (2018), the importance of the endocarp is linked to the relatively slow water uptake by seeds, which represents adaptation to the low soil moisture, once the imbibition has begun. When the availability of water in the soil is enough to completely soak the seeds, the endocarp's humidity can guarantee the germination and, later, the seedlings' establishment in the case of possible lack of water.

Another important relevance to dispersal structure in B. tomentosa is the protection against fire passage, which prevents the embryo damage, as in macaw palm (Bicalho et al., 2016). These facts have ecological significance for maintenance of this species at Cerrado. Seeds without endocarp adhered started the emergence at 25 days, ten days less than others treatment, caused by the removal of the mechanical barrier to water absorption, in comparison with seeds with scarified or non-scarified endocarp adhered (Figure 7), as observed in the absorption curve (Figure 6A). According to the estimates of the regression models (Figure 7), the time to reach $50 \%$ of seedlings emergence $\left(\mathrm{te}_{50}\right)$ was 29 days in seeds without endocarp, whereas the other treatments did not reach te ${ }_{50}$. The presence of damaging fungi in the endocarp may have prevented the seeds from reaching te ${ }_{50}$ on laboratory conditions; however, in nature, the balance between beneficial and damaging microorganisms plays a fundamental role in the seed germination.
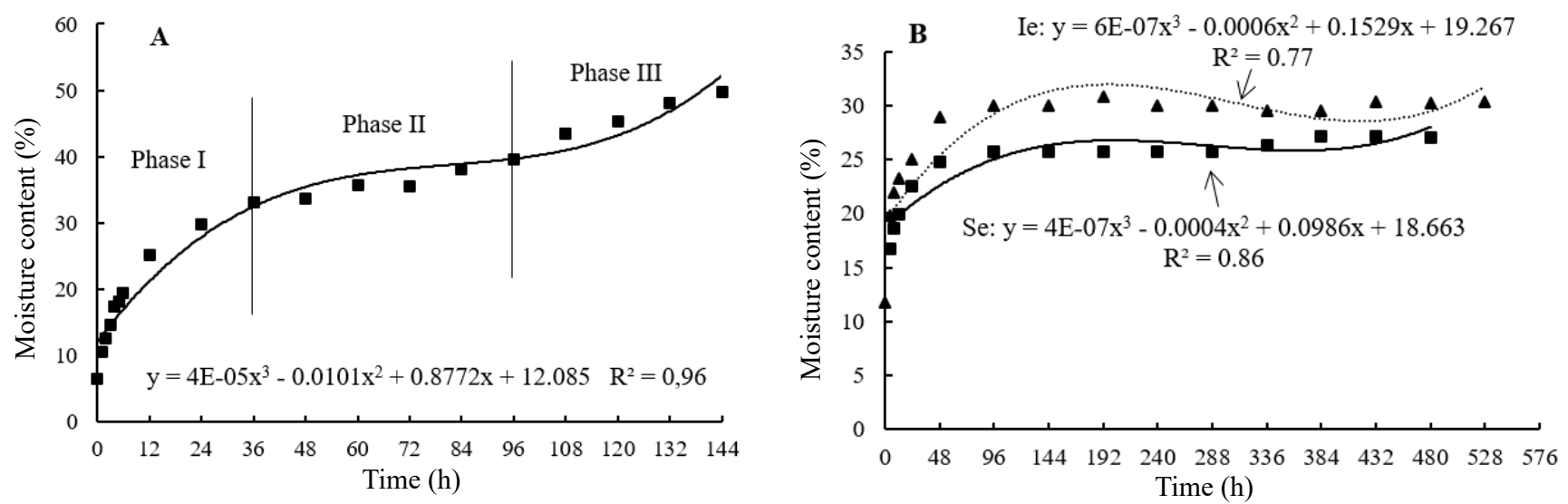

Error bars represent standard errors.

Figure 6. Water absorption curve in Buchenavia tomentosa Eichler seeds (A), in seeds with scarified endocarp adhered (Se) and intact endocarp (le) (B). 


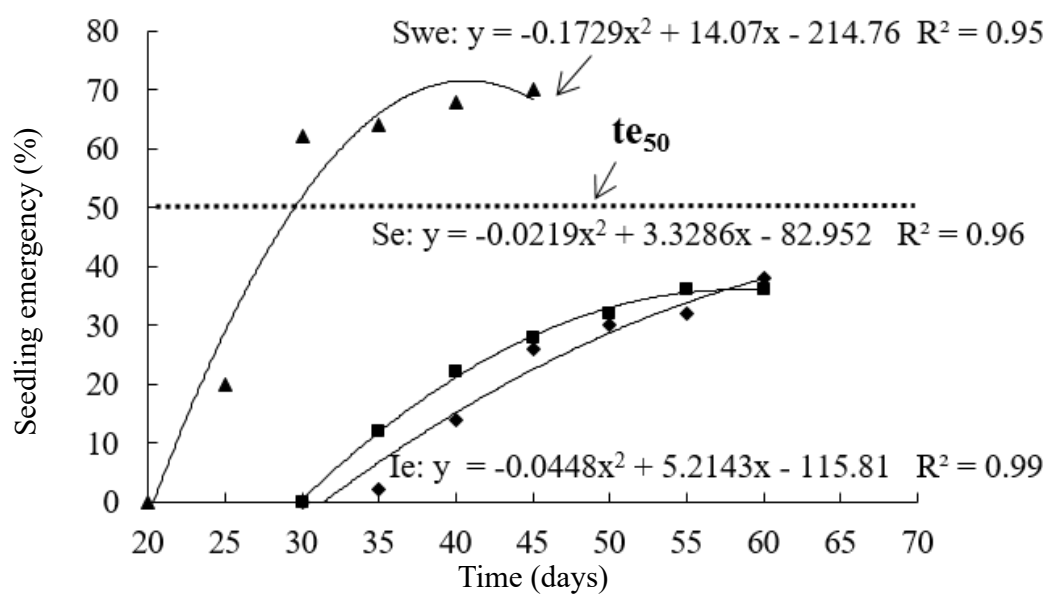

Figure 7. Percentage of seedlings emergence of Buchenavia tomentosa Eichler from seeds without endocarp adhered (Swe), seed with scarified endocarp (Se) and seed with intact endocarp (le).

The endocarp can be removed in the field for dispersers. When it happens, they contribute to accelerate the germination and seed emergence due to the faster water absorption. On the other hand, in scenarios with reduced rainfall, the structure acts in the maintenance of the moisture until the seeds complete the germination process, showing their importance for B. tomentosa.

\section{CONCLUSIONS}

The basis temperatures determined by models to reach $50 \%$ of $B$. tomentosa Eichler germination are: $\mathrm{T}_{\mathrm{b}}$ of $9,23^{\circ} \mathrm{C}$ and $T_{\max }$ of $44,6^{\circ} \mathrm{C}$; and the seeds without endocarp adhered needs average $89.71{ }^{\circ} \mathrm{C}$.days to germinate. Around the optimal temperature of $30^{\circ} \mathrm{C}$, the seedlings showed higher root and aerial part length and higher root dry mass.

The endocarp adhered to the seeds retard but does not prevent water absorption in $B$. tomentosa seeds.

\section{ACKNOWLEDGEMENT}

The authors thank the Programa de Pós-graduação em Agricultura Tropical of the Universidade Federal de Mato Grosso for the infrastructure available, and the Coordenação de Aperfeiçoamento de Pessoal de Nível Superior (CAPES) for the financial support to the first author.

\section{REFERENCES}

BASKIN, C.C.; BASKIN, J.M. Seeds: ecology, biogeography and evolution of dormancy and germination. $2^{\text {nd }}$ ed. San Diego: Academic Press, 2014.

BASKIN, C.C.; ZACKRISSON, O.; BASKIN, J.M. Role of warm stratification in promoting germination of seeds of Empetrum hermaphroditum (Empetraceae), a circumboreal species with a stony endocarp. American Journal of Botany, v.89, n.3, p.486-493, 2002. https://bsapubs.onlinelibrary.wiley.com/doi/pdf/10.3732/ajb.89.3.486

BASKIN, J.M.; BASKIN, C.C. A classification system for seed dormancy. Seed Science Research, v.14, n.1, p.1-16, 2004. https://www. cambridge.org/core/journals/seed-science-research/article/classification-system-forseeddormancy/024181C2EEE1FC55B9D757866 $0 A 5 C B 66$

BEWLEY, J.D. Seed germination and dormancy. The Plant Cell, v.9, p.1055-1066, 1997. https://www.ncbi.nlm.nih.gov/pmc/articles/ PMC156979/pdf/091055.pdf 
BEWLEY, J.D; BLACK, M. Seeds: physiology of development and germination. $2^{\text {nd }}$ ed. Boston: Springer, 1994. p.149-153.

BICALHO, E.M.; ROSA, B.L.; SOUZA, A.E.D.; RIOS, C.O.; PEREIRA, E.G. Do the structures of macaw palm fruit protect seeds in a fire-prone environment? Acta Botanica Brasilica, v.30, n.4, p.540-548, 2016. http://www.scielo.br/scielo.php?pid=S010233062016000400540\&script=sci_arttext

BRADFORD, K.J. Applications of hydrothermal time to quantifying and modeling seed germination and dormancy. Weed Science, v.50, n.2, p.248-260, 2002. http://www.bioone.org/doi/pdf/10.1614/00431745\%282002\%29050\%5B0248\%3AAOHTTQ\%5D2.0.CO\%3B2

BRANCALION, P.H.S.; NOVEMBRE, A.D.D.L.C.; RODRIGUES, R.R. Temperatura ótima de germinação de sementes de espécies arbóreas brasileiras. Revista Brasileira de Sementes, v.32, n.4, p.15-21, 2010. http://www.producao.usp.br/bitstream/handle/ BDPI/5328/art_NOVEMBRE_Temperatura_otima_de_germinacao_de_sementes_de_2010.pdf?sequence=1\&isAllowed=y

BRASIL. Ministério da Agricultura, Pecuária e Abastecimento. Regras para análise de sementes. Ministério da Agricultura, Pecuária e Abastecimento. Secretaria de Defesa Agropecuária. Brasília, DF: MAPA/ACS, 2009. 395p. http://www.agricultura.gov.br/arq_ editor/file/2946_regras_analise_sementes.pdf

CAMARGO, J.L.C.; FERRAZ, I.D.K.; MESQUITA, M.R.; SANTOS, B.A.; BRUM, H.D. Guia de propágulos e plântulas da Amazônia. v.1. Manaus: INPA, 2008. p.50-51.

CAMPOS-FILHO, E.M.; SARTORELLI, P.A.R. Guia de identificação de espécies-chave para a restauração florestal na região de Alto Teles Pires Mato Grosso. São Paulo: The Nature Conservancy, 2015. https://www.nature.org/media/brasil/guia-mt.pdf

CARDOSO, V.J.M; PEREIRA, F.J.M. Dependência térmica da germinação de sementes de Drymaria cordata (L.) Willd. ex Roem. \& Schult. (Cariophyllaceae). Acta Botanica Brasilica, v.23, n.2, p.305-312, 2009. http://www.scielo.br/pdf/abb/v23n2/v23n2a02

COCHRANE, A.; HOYLE, G.L.; YATES, C.J.; WOOD, J.; NICOTRA, A.B. Predicting the impact of increasing temperatures on seed germination among populations of Western Australian Banksia (Proteaceae). Seed Science Research, v.24, n.3, p.195-205, 2014. https://doi.org/10.1017/S096025851400018X

FARIAS, J.; SANCHEZ, M.; ABREU, M.F.; PEDRONI, F. Seed dispersal and predation of Buchenavia tomentosa Eichler (Combretaceae) in a Cerrado sensu stricto, midwest Brazil. Brazilian Journal of Biology, v.75, n.4, p.88-96, 2015. http://www.scielo.br/pdf/bjb/ v75n4s1/1519-6984-bjb-1519-698406214.pdf

FLORES, A.V.; BORGES, E.E.D.L.; GUIMARÃES, V.M.; ATAÍDE, G.D.M.; CASTRO, R.V.O. Germination of Melanoxylon brauna Schott seeds in different temperatures. Revista Árvore, v.38, n.6, p.1147-1154, 2014. http://www.scielo.br/pdf/rarv/v38n6/a19v38n6.pdf

HAMPTON, J.G.; TEKRONY, D.M. Handbook of vigour test methods. Zurich: The International Seed Testing Association (ISTA), 1995.

HARDEGREE, S.P. Predicting germination response to temperature. I. Cardinal-temperature models and subpopulation-specific regression. Annals of Botany, v.97, n.6, p.1115-1125, 2006. https://academic.oup.com/aob/article/97/6/1115/207352

INMET. Instituto Nacional de Meteorologia. 2018. http://www.inmet.gov.br/portal/

LAMARCA, E.V.; VENDRAME, C.; BARBEDO, C.J. Thermal requirements for the seeds of Brazilian species of Eugenia (Myrtaceae) according to their origin. Acta Botanica Brasilica, v.25, n.2, p.293-300, 2011. http://www.scielo.br/pdf/abb/v25n2/a05v25n2

MAGUIRE, J.D. Speed of germination-aid in selection and evaluation for seedling emergence and vigor. Crop Science, v.2, n.1, p.176$177,1962$.

MATTANA, E.; SACANDE, M.; BRADAMANTE, G.; GOMEZ-BARREIRO, P.; SANOGO, S.; ULIAN, T. Understanding biological and ecological factors affecting seed germination of the multipurpose tree Anogeissus leiocarpa. Plant Biology, v.20, p.602-609, 2018. https://onlinelibrary.wiley.com/doi/abs/10.1111/plb.12702

MATTANA, E.; SACANDE, M.; SANOGO, K.A.; LIRA, R.; GOMEZ-BARREIRO, P.; ROGLEDI, M.; ULIAN, T. Thermal requirements for seed germination of underutilized Lippia species. South African Journal of Botany, v.109, p.223-230, 2017. https://www.sciencedirect. com/science/article/pii/S0254629916300424

MENDONÇA, R.C.; FELFILI, J.M.; WALTER, B.M.T.; SILVA-JÚNIOR, M.C.; REZENDE, A.V.; FILGUEIRAS, T.S.; NOGUEIRA, P.E.; FAGG, C.W. Flora vascular do bioma cerrado: checklist com 12.356 espécies. In: SANO, S.M.; ALMEIDA, S.P.; RIBEIRO, J.F. (ed.). Cerrado: ecologia e flora. v.2. Brasília: EMBRAPA, 2008. p.421-1279. 
NAKAGAWA, J. Testes de vigor baseados no desempenho de plântulas. In: KRZYZANOWSKY, F.C.; VIEIRA, R.D.; FRANÇA-NETO, J.B. (ed.). Vigor de sementes: conceitos e testes. Londrina: ABRATES, 1999. p.2.1-2.24.

NORDEN, N.; DAWS, M.I.; ANTOINE, C.; GONZALEZ, M.A.; GARWOOD, N.C.; CHAVE, J. The relationship between seed mass and mean time to germination for 1037 tree species across five tropical forests. Functional Ecology, v.23, p.203-210, 2009. https:// besjournals.onlinelibrary.wiley.com/doi/full/10.1111/j.1365-2435.2008.01477.x

PACHECO, M.V.; MATOS, V.P.; FELICIANO, A.L.P.; FERREIRA, R.L.C. Germinação de sementes e crescimento inicial de plântulas de Tabebuia aurea (Silva Manso) Benth. \& Hook f. ex S. Moore. Ciência Florestal, v.18, n.2, p.143-150, 2008. https://periodicos.ufsm. br/index.php/cienciaflorestal/article/viewFile/452/349

PARMOON, G.; MOOSAVI, S.A.; AKBARI, H.; EBADI, A. Quantifying cardinal temperatures and thermal time required for germination of Silybum marianum seed. The Crop Journal, v.3, n. 2, p.145-151, 2015. https://www.sciencedirect.com/science/article/pii/ S2214514115000136

PIRES, L.A.; CARDOSO, V.J.M.; JOLY, C.A.; RODRIGUES, R.R. Germination of Ocotea pulchella (Nees) Mez (Lauraceae) seeds in laboratory and natural restinga environment conditions. Brazilian Journal of Biology, v.69, n.3, p.935-942, 2009. http://www.scielo. $\mathrm{br} / \mathrm{pdf} / \mathrm{bjb} / \mathrm{v} 69 \mathrm{n} 3 / \mathrm{v} 69 \mathrm{n} 3 \mathrm{a} 23 . \mathrm{pdf}$

REYS, P.; CAMARGO M.G.G.; GROMBONE-GUARATINI, M.T.; TEIXEIRA, A.P.; ASSIS, M.A.; MORELLATO, L.P.C. Structure and floristic composition of a Cerrado sensu stricto and its relevance to ecological restauration. Hoehnea, v.40, n.3, p.449-464, 2013. http:// dx.doi.org/10.1590/S2236-89062013000300005

SILVEIRA, C.E.; PALHARES, D.; PEREIRA, L.A.; PEREIRA, K.B.; SILVA, F.A. Strategies of plant establishment of two Cerrado species: Byrsonima basiloba Juss. (Malpighiaceae) and Eugenia dysenterica Mart. ex DC (Myrtaceae). Plant Species Biology, v.28, p.130-137, 2012. https://esj-journals.onlinelibrary.wiley.com/doi/full/10.1111/j.1442-1984.2012.00366.x

TRIBOUILLOIS, H.; DÜRR, C.; DEMILLY, D.; WAGNER, M.H.; JUSTES, E. Determination of germination response to temperature and water potential for a wide range of cover crop species and related functional groups. PloS One, v.11, n.8, 2016. https://journals. plos.org/plosone/article?id=10.1371/journal.pone.0161185

TRUDGILL, D.L.; SQUIRE, G.R.; THOMPSON, K. A thermal time basis for comparing the germination requirements of some British herbaceous plants. The New Phytologist, v.145, p.107-114, 2000. https://nph.onlinelibrary.wiley.com/doi/pdf/10.1046/j.14698137.2000.00554.x use, distribution, and reproduction in any medium, provided the original work is properly cited. 